\title{
Editorial
}

\section{Será o fim do PROSAB?}

Revista Engenharia Sanitária e Ambiental já publicou dezenas de artigos que 1 resultaram de pesquisas inovadoras do Programa de Pesquisa em Saneamento Básico - PROSAB. Além disso, centenas de trabalhos técnicos foram publicados em congressos, nacionais e internacionais, e em revistas especializadas no Brasil e no exterior, oriundos justamente das pesquisas do programa.

Criado há mais de 12 anos, o PROSAB apresentava a característica inovadora de desenvolver seus trabalhos por meio de redes de pesquisa, em que universidades - tanto as mais experientes no setor, como os centros acadêmicos emergentes - e empresas de saneamento se uniram com o objetivo de trocar experiências, informações, metodologias, e trabalhar de forma complementar, assegurando uma fantástica cooperação e evitando superposições e lacunas temáticas entre os diferentes projetos beneficiados.

A participação de bolsistas e estagiários dos cursos de graduação, de mestrandos e doutorandos, os encontros técnicos e regulares de discussão das diferentes redes formadas, a presença de experientes consultores ad-hoc acompanhando e aprovando todo o projeto, fez o PROSAB estender-se muito além do simples financiamento a projetos, como se caracteriza a ajuda periódica que os órgãos oficiais costumam prestar aos centros acadêmicos.

Pois vejam, meus amigos, que uma descontinuidade no desenvolvimento do programa já é observada, tendo-se passado mais de dez meses desde o encerramento dos últimos projetos, sem que um novo e esperado edital tenha sido lançado. Sem dúvida já se verificam consequências negativas no planejamento das instituições de ensino e pesquisa, perda de jovens pesquisadores e, certamente, impactos indesejados no setor.

É possível que, entre o dia em que escrevo este editorial - início de outubro - e a publicação deste número de RESA, a situação se reverta. No entanto, nunca é demais lembrar como o PROSAB tem sido útil ao setor de saneamento e meio ambiente, ao meio acadêmico e ao próprio país. Com seu primeiro objetivo de buscar soluções adequadas e de custo condizente com nossa realidade, o PROSAB extrapola quaisquer interesses para se caracterizar como um programa dedicado ao desenvolvimento do saneamento no Brasil. Com a palavra, seus gestores, CAIXA, CNPq, e FINEP.

Que continue nos seus peculiares e ótimos moldes, é o que espera o meio técnico, e, de modo particular a ABES. 